\title{
KRT17 Gene
}

National Cancer Institute

\section{Source}

National Cancer Institute. KRT17 Gene. NCI Thesaurus. Code C105977.

This gene plays a role in the development of epidermal appendages. 